\title{
Diurnal Variations in Water Potential and Gas Exchanges in Two-Hybrid Oil Palms Under Water Deficit
}

\author{
Igor V. de Oliveira ${ }^{1}$, Rodrigo O. Aguiar ${ }^{2}$, Clenes C. Lima $^{2}$, Roberto L. Cunha ${ }^{3}$, Wilton P. da Cruz ${ }^{2}$, \\ Claudete R. da Silva ${ }^{2}$, Vicente F. A. Silva ${ }^{2}$, Josiane P. da Silva ${ }^{2}$, Fábio I. M. Carvalho ${ }^{2}$, Luiza H. da S. Martins ${ }^{2}$, \\ Priscilla A. Silva ${ }^{2} \&$ Hugo A. Pinheiro ${ }^{2}$ \\ ${ }^{1}$ Federal University of South and Southeast Pará, Marabá, Brazil \\ ${ }^{2}$ Federal Rural University of the Amazon, Belém, Brazil \\ ${ }^{3}$ Laboratory of Sustainable Systems Analysis, Embrapa Eastern Amazon, Belém, Brazil \\ Correspondence: Priscilla A. Silva, Federal Rural University of the Amazon, Belém, PA, Brazil. Tel: \\ 55-91-981-443-174. E-mail: prisciandra@yahoo.com.br
}

Received: August 17, 2020

doi:10.5539/jas.v12n12p75

\author{
Accepted: October 19, $2020 \quad$ Online Published: November 15, 2020 \\ URL: https://doi.org/10.5539/jas.v12n12p75
}

\begin{abstract}
Oil palm (Elaeis guineensis Jacq.) presents considerable sensitivity to water deficit and the identification of stress-tolerant hybrids is a strategy to improve the adaptation and growth of plants throughout the annual dry seasons. For this reason, we examined possible differences in water deficit tolerance in two oil palm hybrids (BRS Manicoré and BRS C 2501) subjected to moderate drought conditions. The comparison of hybrids was performed using diurnal curves of leaf water potential $\left(\Psi_{w}\right)$, gas exchanges, and biochemical variables, such as chloroplast pigments and enzymes analysis. The experiment was carried out in a completely randomized design, in a $2 \times 2 \times 13$ factorial scheme resulting from the combination of two hybrids versus two water regimes, and thirteen evaluation schedules. Regardless of the water regime, the maximum average value of net assimilation rates of $\mathrm{CO}_{2}(A)$, stomatal conductance to water vapor $\left(g_{s}\right)$, and water use efficiency $(A / E)$ in both hybrids was registered at $8 \mathrm{~h}$. Peaks of $A, g_{s}$, and $A / E$ coincided with milder climatic conditions during the morning. While decreases in these variables were observed with increases in air temperature and vapor pressure deficit between leaf and atmosphere throughout the day. The water deficit induced significant increases in the total carotenoids levels of BRS C 2501 (62\%) and BRS Manicoré (220\%), while chlorophyll $a$ content was significantly reduced only in BRS C 2501 (36\%) and chlorophyll $b$ only in Manicoré (34\%). It also mediated significant increases in the activities of glycolate and catalase oxidase in both hybrids; however, such increases were more expressive in BRS C 2501 than in BRS Manicoré. In conclusion, it can be inferred that BRS Manicoré presents more favorable physiological and biochemical responses to the water deficit imposed compared to BRS C 2501.
\end{abstract}

Keywords: catalase, chlorophyll, vapor pressure deficit, photosynthesis, oxidase of glycolate

\section{Introduction}

Elaeis guineensis (Jacq.) and Elaeis oleifera [(H.B.K.) Cortes] are oil palm species of relevant agronomic interest. The first is used in the formation of commercial plantations for oil production given the great productivity and yield of the fruits. The second; being more rustic, is used as a source of genetic variability for improving the first (Chia, Lopes, Cunha, Rocha, \& Rios, 2012). Palm oil has great economic value due to its use in the manufacture of food, medicines, cosmetics, soaps, and; more recently, biodiesel (Homma, Furlan Júnior, \& Carvalho, 2000; Veiga \& Furia, 2000; Trindade, Poltronieri, \& Furlan Júnior, 2005; Boari, 2008).

The State of Pará is the largest national producer of oil palm, accounting for about $83 \%$ of the Brazilian production of fruit bunches, covering 58895 hectares of planted area (Brazilian Institute of Geography and Statistics [IBGE], 2014). However, oil palm plantation areas in Brazil are small when compared to 17.32 million hectares (Mha) areas cultivated worldwide, being the average production $3.214 \mathrm{t} / \mathrm{ha}$ (Food and Agriculture Organization [FAO], 2015).

The planting of oil palm is limited by several factors, among them the climatic requirements inherent to the species itself, which does not tolerate periods of water deficiency (Bastos et al., 2001). Temperature variations throughout the day and between seasons in Pará are small and therefore, should not affect the production of 
species. However, the water deficit in some regions, as reviewed by Carvalho (2000); Gawankar, Devmore1, Jamadagni, Sagvekar, and Hameed (2003), can lead to a reduction in female inflorescence and consequent fruit formation problems, since the number of fresh fruit bunches depends upon the number of female productive inflorescences. As reported by Waraich, Ahmad, Ashraf, Saifullah, and Ahmad (2011), the water deficit reduces photosynthetic rate, chlorophyll content, stomatal conductance, transpiration rate, relative leaf water content, and destroys some physiological processes, which ultimately reduce plant growth and development.

Under conditions of water deficit, photosynthesis can be reduced in response to a breakdown and/or reduction in electron transport rates and quantum production of photosystems, verified through chlorophyll $a$ fluorescence variable (Asada, 1999). These photochemical responses probably preceded by reductions in the activities of several enzymes related to the biochemical phase of photosynthesis, reducing the fixation of $\mathrm{CO}_{2}$ and production of trioses-phosphates (Lawlor, 1995).

On the other hand, the management of plant nutrients is very helpful to enhance water use efficiency $(A / E)$ by reducing the toxicity of reactive oxygen species (ROS) produced under water-limited conditions, increasing the concentration of antioxidants like superoxide dismutase (SOD); Catalase (CAT) and peroxidase (POD) in the plants' cells. These antioxidants scavenge ROS, reduce photo-oxidation, maintain the integrity of chloroplast membrane, and increase the photosynthetic rate in the crop plants, which in turn enhances the $A / E$ (Waraich, Ahmad, Ashraf, Saifullah, \& Ahmad, 2011).

Since different oil palm hybrids can show relative variability in their responses to water deficit (Suresh, Nagamani, Kantha, \& Kumar, 2012), the use of oil palm genotypes more tolerant to water shortage could be an interesting strategy to alleviate the production problem of areas subject to long periods of drought. Thus, the objective of this work was to evaluate the capacity of water deficit tolerance of the BRS Manicoré and BRS C 2501 oil palm hybrids through physiological and biochemical variables.

\section{Material and Methods}

\subsection{Plant Material and Experimental Conditions}

In Brazil, Embrapa Western Amazon developed two oil palm hybrids (BRS Manicoré and BRS C 2501) for greater resistance to fatal yellowing and greater productivity (Cunha \& Lopes, 2010). For this reason, these two genetic materials have been very much in demand for the implementation of new crop plantations. However, the responses of these hybrids to the water deficit are not yet well known.

The experiment was carried out at the greenhouse of the Agrarian Science Institute of the Federal Rural University of the Amazon, Belém-PA, Brazil ( $01^{\circ} 28^{\prime} 03^{\prime \prime}$ S, $48^{\circ} 29^{\prime} 18^{\prime \prime}$ W) in July 2013. Pre-germinated oil palm seeds of the BRS Manicoré and BRS C 2501 hybrids were sown in polyethylene trays. After 30 days, the seedlings were transplanted into $50 \mathrm{~L}$ polyethylene pots filled with $40 \mathrm{~kg}$ of Yellow Latosol, medium-texture, air-dried, and sieved. The substrate $\mathrm{pH}$ was corrected to 6.0 using $30 \mathrm{~g}$ of dolomitic limestone per pot. Additional fertilization was applied as $5 \mathrm{~g}$ of NPK 20-20-20 (w/w) at 15-day intervals and $2.5 \mathrm{~g}$ of magnesium sulfate at 30-day intervals per pot (Franzini \& Silva, 2012). The Irrigation was daily performed early in the morning and the volume of water applied was estimated to replace the water lost by evapotranspiration $(\sim 1.5 \mathrm{~L}$ per pot), determined by the method of the weight difference of each experimental unit (pot + soil + plant) concerning its saturated and drained weights (in field capacity).

When the seedlings were twelve months old, they were used for the definitive experiment, which consisted of two treatments: (i) Irrigated, whose plants were irrigated diurnal, and (ii) Water deficit, induced by the progressive evapotranspiration in the soil-plant system due to complete suspension of irrigation. Treatments were compared when leaf water potential in the morning $\left(\Psi_{a m}\right)$, measured between 4:00 and 5:00 h, it reached about $-2.0 \mathrm{MPa}$ for the stressed plants of both hybrids. For the comparison of treatments, the physiological variables (water potential and gas exchange) were determined throughout the day, between 6:00 and 18:00 h, at hourly intervals between measurements. Biochemical variables (chloroplast pigments and enzymatic assays) were determined only at the time of day corresponding to the maximum $A$.

\subsection{Leaf Water Potential}

It was determined using a Scholander pressure pump (mod. Pms Instrument Co., Corvallis, USA) as described by DaMatta, Maestri, Barros, and Regazzi (1993). For evaluations of $\Psi_{w}$ medium leaflets of the third or fourth mature leaf were selected from the apex, that is, from the arrowleaf. 


\subsection{Gas Exchange}

The net assimilation rates of $\mathrm{CO}_{2}(A)$, stomatal conductance to water vapor $\left(g_{s}\right)$, transpiration $(E)$, the intercellular concentration of $\mathrm{CO}_{2}\left(C_{i}\right)$, and leaf temperature $\left(T_{\text {fol }}\right)$ were measured utilizing an infrared gas analyzer (LCpro+, ADC BioScientific Ltd., Hoddesdon, UK). Photosynthetically active radiation (PAR) was determined using a quantum sensor attached to the gas analyzer chamber. All evaluations were carried out under natural $\mathrm{CO}_{2}$ and PAR concentration, that is, the one available at each hour of the day. The vapor pressure deficit between leaf and atmosphere $\left(\delta_{e}\right)$ was calculated from the data obtained for $T_{a r}$ and $T_{\text {fol }}$ (Landsberg, 1986) and the instant water use efficiency $(A / E)$.

\subsection{Chloroplast Pigments}

Chlorophylls $a$ and $b$ and the total carotenoids were extracted and quantified according to Lichthenthaler (1987), with modifications. Leaf samples were macerated in $8 \mathrm{~mL}$ of $80 \%$ acetone in the presence of $0.2 \mathrm{~g}$ of $\mathrm{CaCO}_{3}$ and the resulting homogenate was centrifuged at $3500 \times \mathrm{g}$, for $10 \mathrm{~min}$, at $4{ }^{\circ} \mathrm{C}$. Then, the supernatant was collected and reserved. The extraction was repeated for the residue three times, with $5 \mathrm{~mL}$ of $80 \%$ acetone each. The supernatants resulting from each centrifugation were combined with the first to obtain the final extract, which volume was adjusted to $25 \mathrm{~mL}$ with $80 \%$ acetone. All these steps were performed in the presence of green light, avoiding direct radiation in the samples. The absorbance (ABS) of the samples was obtained in a spectrophotometer (GenesysTM ${ }^{10}$ series, Thermo Electron Co., Wisconsin, USA) at $470 ; 646.8$, and $663.2 \mathrm{~nm}$. The total concentrations of chlorophylls and carotenoids (g pigment $\mathrm{kg}^{-1} \mathrm{MS}$ ) were calculated according to Lichthenthaler (1987).

\subsection{Obtaining of Enzymatic Extracts}

The extraction of glycolate oxidase $\left(\mathrm{GLO}_{\mathrm{x}}\right.$, E.C. 1.1.3.15) was carried out in $3 \mathrm{~mL}$ of $50 \mathrm{mM}$ of Tris- $\mathrm{HCl}$ buffer $0.3 \mathrm{M}$ (pH 7.8), with $5 \mathrm{mM}$ of dithiothreitol, $0.01 \%$ (v/v) of Triton X-100, and $30 \mathrm{mg}$ of PVPP (Booker, Reid, Brunschon-Harti, Fiscus, \& Miller, 1997). Catalase (CAT, E.C. 1.11.1.6) were extracted in TFK $50 \mathrm{mM}$ (pH 7.0), with $2 \mathrm{mM}$ of EDTA, $0.1 \%(\mathrm{v} / \mathrm{v})$ of Triton X-100, $20 \mathrm{mM}$ of ascorbate and $30 \mathrm{mg}$ of PVPP (Havir \& McHale, 1987). The homogenates resulting from the extraction of $\mathrm{GLO}_{\mathrm{x}}$ and CAT were centrifuged respectively at $15,000 \times \mathrm{g}$ (for $15 \mathrm{~min}$ ) and $30,000 \times \mathrm{g}$ (for $20 \mathrm{~min}$ ), both at $4{ }^{\circ} \mathrm{C}$. For the enzymatic analyzes, the obtained supernatants were used, which concentrations of total soluble proteins were determined by the method of Bradford (1976).

\subsection{Glycolate Oxidase Activity}

$\mathrm{GLO}_{\mathrm{x}}$ activity was determined by the formation of phenylhydrazone glycolate following the increase in ABS at $324 \mathrm{~nm}$ according to Booker et al. (1997). The extinction coefficient of $17 \mathrm{mM}^{-1} \mathrm{~cm}^{-1}$ of the phenylhydrazine glycolate was used for the calculations and the results expressed in $\mathrm{mM} \mathrm{min}{ }^{-1} \mathrm{mg}^{-1}$ protein. CAT activity was determined by monitoring the decrease in ABS at $240 \mathrm{~nm}$ and for calculations, it was considered that $1 \mathrm{U}$ of CAT is the amount of enzyme capable of oxidizing $1 \mu \mathrm{moL}$ of $\mathrm{H}_{2} \mathrm{O}_{2} \min ^{-1}$ (Havir \& McHale, 1987).

\subsection{Result Analysis}

The experiment was installed in a completely randomized design in a $2 \times 2 \times 13$ factorial scheme, with two hybrids (BRS Manicoré and BRS C 2501), two water regimes (irrigated and water deficit), and thirteen evaluation schedules 6:00, 7:00, 8:00, 9:00, 10:00, 11:00, 12:00, 13:00, 14:00, 15:00, 16:00, 17:00, 18:00h (local time; UTC-03:00) and six repetitions per treatment combination. Being each repetition consisted of one plant per pot. The diurnal curves of water potential and gas exchange were constructed from the means \pm standard deviation (SD) of each variable at each of the pre-established times. From the diurnal curves, the maximum, minimum, and diurnal averages of $\Psi_{w}$ and each gas exchange variable were obtained. These data, as well as those obtained for chlorophylls, carotenoids, and enzymatic activities, were submitted to ANOVA and the comparisons between averages performed by Tukey test $(p<0.05)$, using the SAS statistical package (v. 8.0, 1999, SAS Institute, Cory, USA).

\section{Results}

Diurnal variations of $\Psi_{w}$ in irrigated plants followed similar patterns among hybrids. The values of $\Psi_{w}$ were maximum between 6:00 and 8:00 h. The $\Psi_{w}$ of these plants reached the lowest values between 13:00 and 14:00 h (Figures 1A and 1B). From 15:00 h onwards, the $\Psi_{w}$ increased for both hybrids, reaching at 18:00 $\mathrm{h}$ values close to those at 6:00 h (Figures 1A and 1B). Still, for irrigated plants, there was no difference between averages of $\Psi_{w}$ maximum and minimum or between diurnal averages of $\Psi_{w}$ (Table 1). 
The stressed plants of the BRS C 2501 and BRS Manicore hybrids always presented lower averages of $\Psi_{w}$ than their respective irrigated plants, regardless of the time, showing the negative effect of the water deficit on the water status of the plant (Figures 1A and 1B). The $\Psi_{w}$ of these plants was higher between 6:00 and 8:00 h and lower between 09:00 and 15:00 h (Table 1). The lowest $\Psi_{w}$ average for hybrids BRS C 2501 was -2.71 MPa and $-2.61 \mathrm{MPa}$ to BRS Manicoré, registered at 14:00 h (Table 1). The diurnal average of $\Psi_{w}$ was higher at BRS Manicoré (Table 1).

Table 1. Maximum (Max.) and minimum (Min.) diurnal values and diurnal average (Ave.) of water potential $\left(\Psi_{w}\right)$ in two oil palm hybrids (BRS C 2501 and BRS Manicoré) under full irrigation (Irrigated) and water deficit (Water deficit)

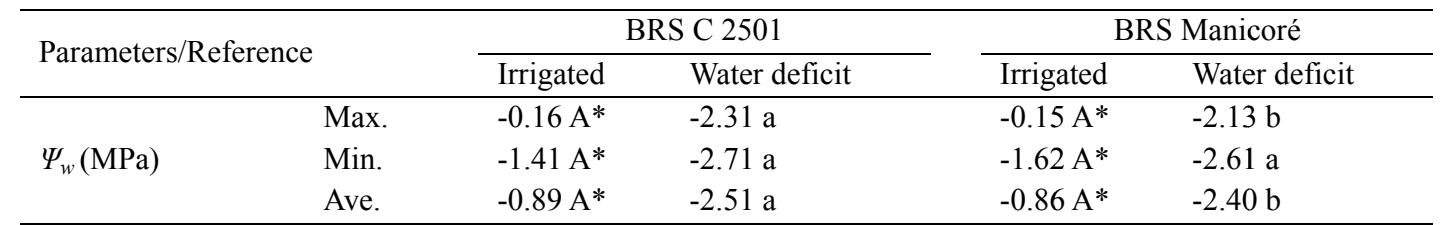

Note. Data represent the averages of six repetitions. Upper and lower case letters on the line compare the different hybrids in the same water regime. Asterisks compare plants from the same hybrid under different water regimes. Different letters and an asterisk denote significant differences between means (Tukey test, $p<0.05$ ).

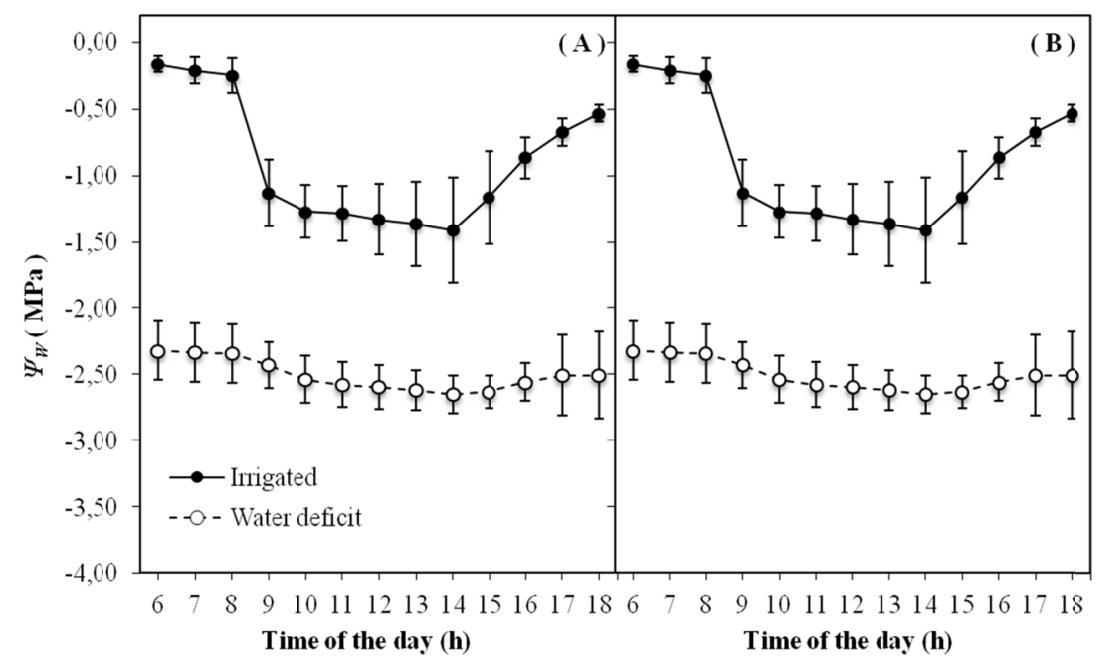

Figure 1. Diurnal course of leaf water potential $\left(\Psi_{w}\right)$ in two oil palm hybrids (BRS C 2501 and BRS Manicoré) under full irrigation (Irrigated) and water deficit (Water Deficit). The data are the average of six repetitions \pm standard deviation $(\mathrm{SD})$

The diurnal variations of $A, g_{s}, E$, and $A / E$ followed similar patterns for irrigated plants compared to each other and for plants in water deficit compared to each other (Figure 2). The maximum peak of $A$ for irrigated plants occurred at 8:00 h for both hybrids (Figures $2 \mathrm{~A}$ and $2 \mathrm{~B}$ ), however, at this time, the average of the hybrid BRS Manicore was higher than in BRS C 2501 (Table 2). From that time on, the values of $A$ decreased until reaching the lowest diurnal values, recorded at 18:00 $\mathrm{h}$ (Figures 2A and 2B). It should be noted that the $A$ of BRS Manicore for this time was higher than that registered for BRS C 2501 (Figures 2A and 2B). The irrigated plants of the BRS Manicoré also showed a higher diurnal average of $A$ than the irrigated plants of the BRS C 2501 hybrid (Table 2).

The water deficit caused remarkable reductions in $A$ for both evaluated hybrids, mainly between 7:00 and 16:00 $\mathrm{h}$ (Figures 2A and 2B). For plants under water deficit in both hybrids, the maximum peak of $A$ also occurred at 8:00 h and as well as for irrigated plants, this peak was higher for BRS Manicoré than for BRS C 2501 (Table 2). From 9:00 h onwards, the $A$ of BRS C 2501 assumed values very close to zero, which only occurred for BRS Manicoré after 12:00 h (Figures 2A and 2B). 


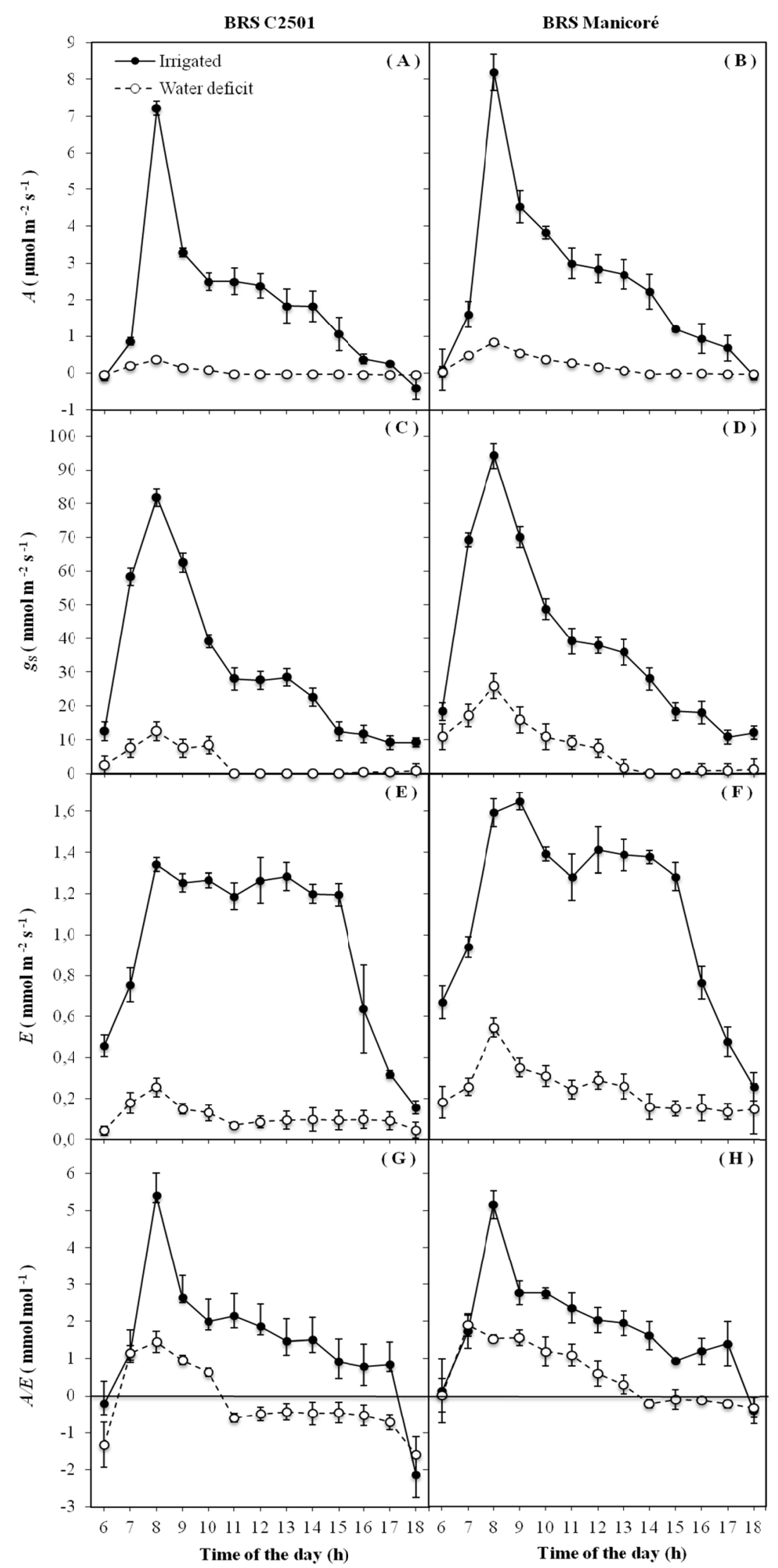

Figure 2. Diurnal course of net assimilation rates $\mathrm{CO}_{2}(A)$, stomatal conductance to water vapor $\left(g_{s}\right)$, transpiration $(E)$, and instant water use efficiency $(A / E)$ in two oil palm hybrids (BRS C 2501 and BRS Manicoré) under full irrigation (Irrigated) and water deficit (Water Deficit). The data are the average of six repetitions \pm SD 
Table 2. Maximum diurnal values (Max.), minimums (Min.), and diurnal averages (Ave.) of the net assimilation rate of $\mathrm{CO}_{2}(A)$, stomatal conductance to water vapor $\left(g_{s}\right)$, transpiration $(E)$, and instant water use efficiency $(A / E)$ in two oil palm hybrids (BRS C 2501 and BRS Manicoré) under full irrigation (Irrigated) and water deficit (Water Deficit)

\begin{tabular}{|c|c|c|c|c|c|}
\hline \multirow{2}{*}{ Parameter/Reference } & & \multicolumn{2}{|c|}{ BRS C 2501} & \multicolumn{2}{|c|}{ BRS Manicoré } \\
\hline & & Irrigated & Water deficit & Irrigated & Water deficit \\
\hline \multirow{3}{*}{$A\left(\mu \mathrm{mol} \mathrm{m}{ }^{-2} \mathrm{~s}^{-1}\right)$} & Max. & $7.22 \mathrm{~B}^{*}$ & $0.36 \mathrm{~b}$ & $8.19 \mathrm{~A}^{*}$ & $0.84 \mathrm{a}$ \\
\hline & Med. & $1.81 \mathrm{~B}^{*}$ & $0.03 \mathrm{~b}$ & $2.44 \mathrm{~A}^{*}$ & $0.20 \mathrm{a}$ \\
\hline & Min. & $-0.49 \mathrm{~A}^{*}$ & $-0.07 b$ & $-0.13 \mathrm{~A}^{*}$ & $-0.04 \mathrm{a}$ \\
\hline \multirow{3}{*}{$g_{\mathrm{s}}\left(\mathrm{mmol} \mathrm{m} \mathrm{m}^{-2} \mathrm{~s}^{-1}\right)$} & Max. & $82 \mathrm{~B}^{*}$ & $12 \mathrm{~b}$ & $94 \mathrm{~A}^{*}$ & $26 \mathrm{a}$ \\
\hline & Med. & $31 \mathrm{~B}^{*}$ & $3 \mathrm{~b}$ & $38 \mathrm{~A}^{*}$ & $8 \mathrm{a}$ \\
\hline & Min. & $8 \mathrm{~A}^{*}$ & $0 \mathrm{a}$ & $11 \mathrm{~A}^{*}$ & $0 \mathrm{a}$ \\
\hline \multirow{3}{*}{$E\left(\mathrm{mmol} \mathrm{m}{ }^{-2} \mathrm{~s}^{-1}\right)$} & Max. & $1.37 \mathrm{~B}^{*}$ & $0.26 \mathrm{~b}$ & $1.65 \mathrm{~A}^{*}$ & $0.55 \mathrm{a}$ \\
\hline & Med. & $0.93 \mathrm{~B}^{*}$ & $0.11 \mathrm{~b}$ & $1.11 \mathrm{~A}^{*}$ & $0.25 \mathrm{a}$ \\
\hline & Min. & $0.18 \mathrm{~B}^{*}$ & $0.03 \mathrm{~b}$ & $0.26 \mathrm{~A}^{*}$ & $0.10 \mathrm{a}$ \\
\hline \multirow{3}{*}{$A / E\left(\mathrm{mmol} \mathrm{mol}{ }^{-1}\right)$} & Max. & $5.40 \mathrm{~A}^{*}$ & $1.45 \mathrm{~b}$ & $5.17 \mathrm{~A}^{*}$ & $1.90 \mathrm{a}$ \\
\hline & Med. & $1.42 \mathrm{~B}^{*}$ & $-0.18 b$ & $1.82 \mathrm{~A}^{*}$ & $0.54 \mathrm{a}$ \\
\hline & Min. & $-2.14 \mathrm{~B}$ & $-1.60 b$ & $-0.40 \mathrm{~A}$ & $-0.31 \mathrm{a}$ \\
\hline
\end{tabular}

Note. Data represent the averages of six repetitions. Upper and lower case letters on the line compare the different hybrids in the same water regime. Asterisks compare plants from the same hybrid under different water regimes. Different letters and an asterisk denote significant differences between means (Tukey test, $p<0.05$ ).

The diurnal $g_{s}$ curves for the irrigated plants of both hybrids followed the same pattern of variation as that obtained for $A$ (Figure 2). Therefore, the $g_{s}$ was very low at 6:00 h and peaked at 8:00 h, with successive decreases to the lowest values of the day, recorded for both at 16:00 h (Figures 2A and 2B). The diurnal values of $g_{s}$ maximum and average for the BRS Manicoré were high than BRS C 2501, while $g_{s}$ minimum value did not differ between the hybrids (Table 2).

In BRS C 2501, $g_{s}$ increased from 6:00 $\mathrm{h}$ to a maximum at 8:00 $\mathrm{h}$ (Figure 2C). After this time, the $g_{s}$ decreased until reaching the lowest diurnal value (Table 2), which occurred after 11:00 h (Figure 2C). For BRS Manicoré, the $g_{s}$ also increased from 6:00 h to a peak at 8:00 h (Figure 2D). After this time, $g_{s}$ in these plants decreased until reaching the lowest diurnal value (Table 2), which occurred at 14:00 h (Figure 2D). The diurnal curves showed that plants under water deficit in BRS Manicoré had higher diurnal averages of $g_{s}$ when compared to BRS C 2501 (Table 2).

$E$ average in the irrigated plants in BRS C 2501 was higher at 8:00 h (Figure 2E). In these plants, $E$ remained high up to 15:00 h (Figure 2E), later it was decreasing until reaching its lowest diurnal value (Table 2), recorded at 18:00 h (Figure 2E). For the irrigated plants of BRS Manicoré, the maximum $E$ value was observed at 9:00 h (Figure 2F) and remained high most of the day (between 10:00 and15:00 h), with $E$ values between 1.28 and $1.41 \mathrm{mmol} \mathrm{m}^{-2} \mathrm{~s}^{-1}$ (Figure 2F). After 15:00 h, $E$ also decreased in these plants until reaching the lowest diurnal value, which was $0.26 \mathrm{mmol} \mathrm{m}^{-2} \mathrm{~s}^{-1}$ recorded at 18:00 h (Figure 2F). The diurnal average of $E$ was higher in the BRS Manicoré plants (Table 2).

The water deficit caused significant reductions of $E$ in both hybrids (Figures 2E and 2F). The $E$ peak for both hybrids also occurred at 8:00 h. However, the maximum $E$ was higher in BRS Manicoré (Figure 2F). $E$ was minimal between 11:00 and 18:00 h for BRS C 2501 and between 14:00 and 18:00 h for BRS Manicoré (Figures $2 \mathrm{E}$ and $2 \mathrm{~F}$ ). To the comparison of the curves, we note that $E$ value was higher to the BRS Manicoré in all hours of the day (Figures $2 \mathrm{E}$ and $2 \mathrm{~F}$ ), which resulted in a higher daily average of $E$ in BRS Manicoré when compared to BRS C 2501 (Table 2).

The $A / E$ in the irrigated plants of BRS C 2501 was maximum at 8:00 h (Figure $2 \mathrm{G}$ ). After this time, the $A / E$ decreased progressively and reached the lowest diurnal value at 18:00 h (Figure $2 \mathrm{G}$ ). The irrigated plants of BRS Manicoré showed the same pattern of diurnal variation of $A / E$, (Figure $2 \mathrm{H}$ ). It is noteworthy that the average diurnal $A / E$ was higher for BRS Manicoré (Table 2).

From 6:00 to 7:00 h, plants under water deficit in both hybrids show increases in $A / E$ coinciding with that of irrigated plants (Figures $2 \mathrm{G}$ and $2 \mathrm{H}$ ). Between 7:00 and 9:00 h, the $A / E$ was maximum for the stressed plants of both hybrids, being higher for the BRS Manicoré (Figures $2 \mathrm{G}$ and $2 \mathrm{H}$ ). Throughout the day, the $A / E$ decreased 
for both hybrids, however, such decreases were more expressive for the BRS C 2501, since the $A / E$ reached negative values after 11:00 h, while this only occurred from 14:00h onwards to BRS Manicoré (Figures $2 \mathrm{G}$ and $2 \mathrm{H})$. Besides, it should be noted that the negative $A / E$ values for BRS C 2501 ranged between -0.43 to -1.60 $\mathrm{mmol} \mathrm{mol}{ }^{-1}$, while for BRS Manicoré between -0.10 to $-0.31 \mathrm{mmol} \mathrm{mol}^{-1}$ (Figures $2 \mathrm{G}$ and $2 \mathrm{H}$ ). Such differences resulted in a higher average diurnal $A / E$ in the hybrid BRS Manicoré (Table 2).

The diurnal curves of $C_{i}$ for the irrigated plants of the two hybrids showed that the highest averages of this variable were recorded between 6:00 and 7:00 h (Figures 3A and 3B). For both hybrids, a strong reduction in $C_{i}$ was recorded at $8: 00 \mathrm{~h}$, coinciding with the maximum peak of $A$ (Figures $3 \mathrm{~A}$ and $3 \mathrm{~B}$ ). The $C_{i}$ in both hybrids remained practically constant between 8:00 to $14: 00 \mathrm{~h}$, and from then on, it gradually increased until 18:00 $\mathrm{h}$. However, the $C_{i}$ values recorded at 18:00 $\mathrm{h}$ for both hybrids remained lower, when compared to those observed in the early morning (Figures $3 \mathrm{~A}$ and $3 \mathrm{~B}$ ).

For both hybrids plants under water deficit, the $C_{i}$ early in the morning was also very high (Figures $3 \mathrm{~A}$ and $3 \mathrm{~B}$ ). From 6:00 h onward, $C_{i}$ values decreased until reaching the lowest diurnal averages, recorded at 12:00 $\mathrm{h}$ (Figures $3 \mathrm{~A}$ and $3 \mathrm{~B}$ ). From 12:00 h, $C_{i}$ in both hybrids increased again progressively, reaching at 18:00 $\mathrm{h}$ values similar to those observed at 6:00 h (Figures 3A and 3B). Comparing the diurnal variations of $C i$, it is evident that the water deficit resulted in higher $C i$ values at almost all times of the day, regardless of the hybrid (Figures $3 \mathrm{G}$ and $3 \mathrm{H}$ ).

PAR, $T_{f o l}$, and $\delta_{e}$ increased throughout the morning, reaching maximum peaks between 12:00 and 13:00 h, followed by decreases during the afternoon (Figures $3 \mathrm{C}$ to $3 \mathrm{H}$ ).

It is important to note that during the peaks of $A, g_{s}, E$, and $A / E(8: 00 \mathrm{~h})$, the mean of PAR and $T_{f o l}$ were 850 $\mu \mathrm{moL} \mathrm{m} \mathrm{s}^{-2}$ and $37{ }^{\circ} \mathrm{C}$ and the $\delta_{e}$ averages were $2.02 \mathrm{kPa}$ for BRS C 2501 and $3.21 \mathrm{kPa}$ for BRS Manicoré (Figure $3 \mathrm{C}$ to $3 \mathrm{H}$ ).

Table 3. Values of Diurnal Maximum (Max), minimum (Min.), and average (Ave.) of intercellular $\mathrm{CO}_{2}\left(C_{i}\right)$ concentration in two oil palm hybrids (BRS C 2501 and BRS Manicoré) under full irrigation (Irrigated) and water deficit

\begin{tabular}{|c|c|c|c|c|c|}
\hline \multirow{2}{*}{\multicolumn{2}{|c|}{ Parameter/Reference }} & \multicolumn{2}{|c|}{ BRS C 2501} & \multicolumn{2}{|c|}{ BRS Manicoré } \\
\hline & & Irrigated & Water deficit & Irrigated & Water deficit \\
\hline \multirow{3}{*}{$C_{i}\left(\mathrm{~mol} \mathrm{~mol}^{-1}\right)$} & Max. & $435 \mathrm{~A}^{*}$ & $546 \mathrm{a}$ & $425 \mathrm{~A}^{*}$ & $494 \mathrm{~b}$ \\
\hline & Med. & $188 \mathrm{~A}^{*}$ & $398 \mathrm{a}$ & $173 \mathrm{~B}^{*}$ & $365 \mathrm{~b}$ \\
\hline & Min. & $110 \mathrm{~A}^{*}$ & $281 \mathrm{a}$ & $105 \mathrm{~A}^{*}$ & $250 \mathrm{~b}$ \\
\hline
\end{tabular}

Note. Data represent the averages of six repetitions. Upper and lower case letters on the line compare the different hybrids in the same water regime. Asterisks compare plants from the same hybrid under different water regimes. Different letters and an asterisk denote significant differences between means (Tukey test, $p<0.05$ ). 


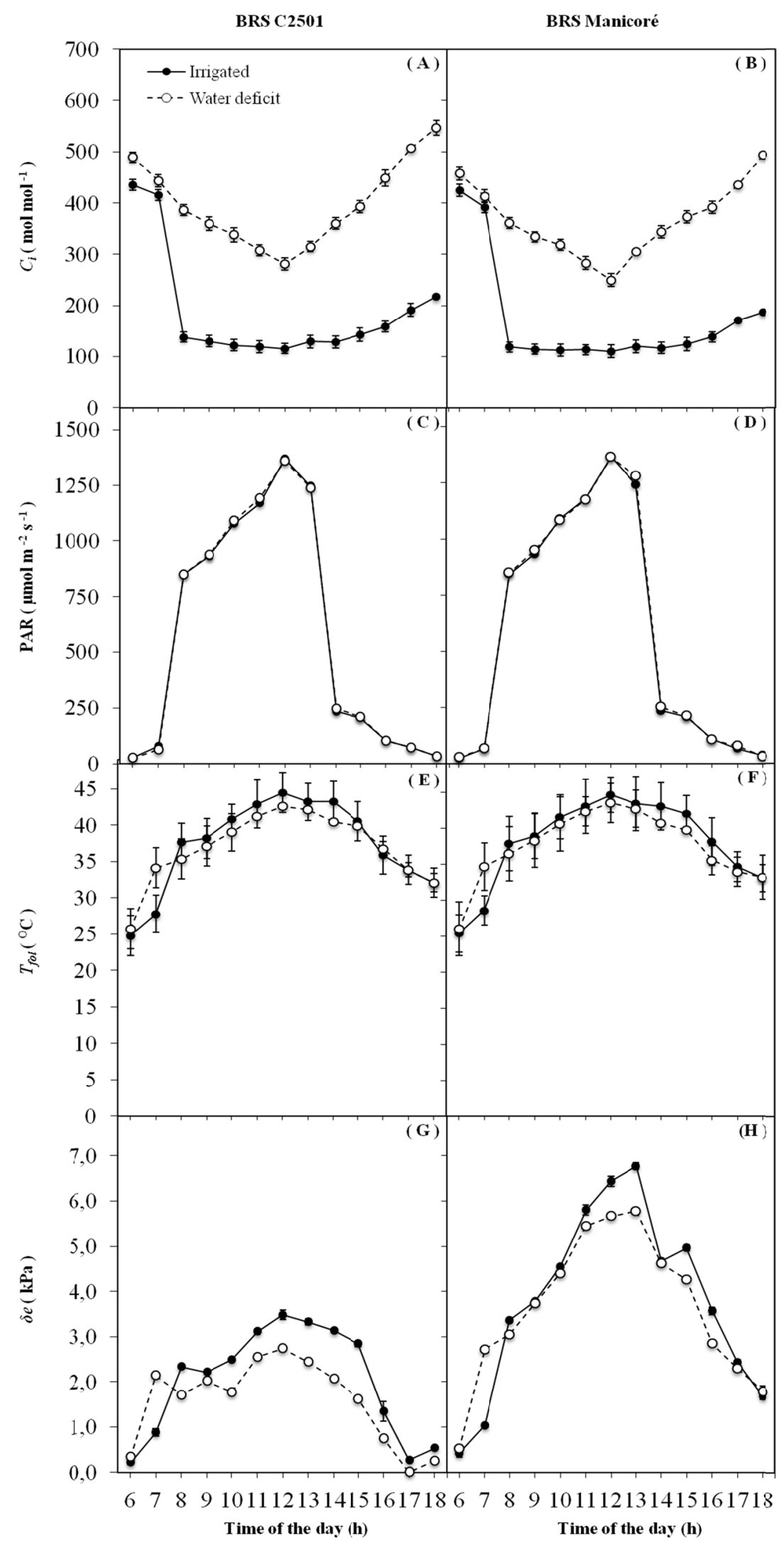

Figure 3. The diurnal course of intercellular $\mathrm{CO}_{2}$ concentrations $\left(C_{i}\right)$, photosynthetically active radiation (PAR), leaf temperature $\left(T_{f o l}\right)$, and the deficit of vapor pressure between leaf and atmosphere $\left(\delta_{e}\right)$ in two oil palm hybrids (BRS C 2501 and BRS Manicoré) under full irrigation (Irrigated) and water deficit (Water deficit). The data are the average of six repetitions $\pm \mathrm{SD}$ 
The results of chloroplast pigments are shown in Table 4. The average of chlorophyll $a(\mathrm{Chl} a)$ in the irrigated plants of BRS C 2501 was higher than in the irrigated plants of BRS Manicoré. Underwater deficit, the concentration of $\mathrm{Chl}$ did not differ between hybrids. The effect of water deficit on the concentration of Chl $a$ was only evident for BRS C 2501, reducing the concentration of this pigment by $36 \%$ concerning irrigated plants.

The means of chlorophyll $b(\mathrm{Chl} b)$ and total carotenoids $\left(\mathrm{CAR}_{T o t}\right)$ did not differ when plants of different hybrids were compared in the same water regime. Concerning the respective irrigated plants, the concentration of $\mathrm{Chl} b$ was reduced only in BRS Manicore (34\%), while the average of $\mathrm{CAR}_{T o t}$ was increased in both hybrids $(62 \%$ in BRS C 2501 and $220 \%$ in BRS Manicoré).

Table 4. Concentrations of chlorophyll $a(\mathrm{Chl} a)$, chlorophyll $b(\mathrm{Chl} b)$, and total carotenoids $\left(\mathrm{CAR}_{T o t}\right)$ in two oil palm hybrids (BRS C 2501 and BRS Manicoré) under full irrigation (Irrigated) and water deficit (Water Deficit).

\begin{tabular}{|c|c|c|c|c|}
\hline \multirow{2}{*}{ Parameter } & \multicolumn{2}{|c|}{ BRS C 2501} & \multicolumn{2}{|c|}{ BRS Manicoré } \\
\hline & Irrigated & Water deficit & Irrigated & Water deficit \\
\hline Chl $a\left(\mathrm{~g} \mathrm{~kg}^{-1} \mathrm{MS}\right)$ & $13.5 \mathrm{~A}^{*}$ & $8.7 \mathrm{a}$ & $8.4 \mathrm{~B}$ & $7.4 \mathrm{a}$ \\
\hline Chl $b\left(\mathrm{~g} \mathrm{~kg}^{-1} \mathrm{MS}\right)$ & $7.4 \mathrm{~A}$ & $5.5 \mathrm{a}$ & $7.1 \mathrm{~A}^{*}$ & $4.7 \mathrm{a}$ \\
\hline $\mathrm{CAR}_{T o t}\left(\mathrm{~g} \mathrm{~kg}^{-1} \mathrm{MS}\right)$ & $0.8 \mathrm{~A}^{*}$ & $1.3 \mathrm{a}$ & $0.5 \mathrm{~A}^{*}$ & $1.6 \mathrm{a}$ \\
\hline
\end{tabular}

Note. Data represent the averages of six repetitions. Upper and lower case letters on the line compare the different hybrids in the same water regime. Asterisks compare plants from the same hybrid under different water regimes. Different letters and an asterisk denote significant differences between means (Tukey test, $p<0.05$ ).

The $\mathrm{GLO}_{\mathrm{x}}$ activity did not differ between irrigated plants of both hybrids (Table 5). In plants under stress, there was an increase in the enzymatic activity of $\mathrm{GLO}_{\mathrm{x}}$ by $68.7 \%$ and $88.2 \%$ for BRS Manicoré and BRS C 2501, respectively (Table 5).

CAT activity did not differ when plants from different hybrids were compared in the same water regime (Table 5). However, the water deficit increased CAT activity in both hybrids, with increases of around $20 \%$ in BRS Manicoré and 55\% in BRS C 2501 (Table 5).

Table 5. Glycolate oxidase $\left(\mathrm{GLO}_{\mathrm{x}}\right)$ and catalase (CAT) activities in two oil palm hybrids (BRS C 2501 and BRS Manicoré) under full irrigation (Irrigated) and water deficit

\begin{tabular}{|c|c|c|c|c|}
\hline \multirow{2}{*}{ Enzyme } & \multicolumn{2}{|c|}{ BRS C 2501} & \multicolumn{2}{|c|}{ BRS Manicoré } \\
\hline & Irrigated & Water deficit & Irrigated & Water deficit \\
\hline $\mathrm{GLO}_{\mathrm{x}}\left(\mathrm{mM} \mathrm{min} \mathrm{mg}^{-1} \mathrm{mg}^{-1}\right.$ protein $)$ & $52.6 \mathrm{~A}^{*}$ & $99.0 \mathrm{a}$ & $50.4 \mathrm{~A}^{*}$ & $85.0 \mathrm{a}$ \\
\hline CAT (U mg ${ }^{-1}$ protein) & $0.042 \mathrm{~A}^{*}$ & $0.065 \mathrm{a}$ & $0.035 \mathrm{~A}^{*}$ & $0.042 \mathrm{a}$ \\
\hline
\end{tabular}

Note. Data represent the averages of six repetitions. Upper and lower case letters on the line compare the different hybrids in the same water regime. Asterisks compare plants from the same hybrid under different water regimes. Different letters and an asterisk denote significant differences between means (Tukey test, $p<0.05$ ).

\section{Discussion}

In irrigated plants, the comparison of both hybrids showed that the lowest $A$ values recorded at the beginning of the morning and the end of the afternoon were coincident with the lowest diurnal means of PAR $\left(30 \mu \mathrm{moL} \mathrm{m}{ }^{-2}\right.$ $\mathrm{s}^{-1}$ ). The maximum peaks of $A$ recorded at $8: 00 \mathrm{~h}$ were coincident with the intermediate values of PAR (850 $\left.\mu \mathrm{moL} \mathrm{m} \mathrm{s}^{-2}\right)$ and the decreases of $A\left(11: 00\right.$ to 13:00 h) were coincident with the PAR peak (1300 $\left.\mu \mathrm{moL} \mathrm{m}^{-2} \mathrm{~s}^{-1}\right)$.

The analysis of the diurnal curves of $A$ and $C_{i}$ for the irrigated plants of both hybrids allows us to infer that the expressive increase in $A$ occurring from 6:00 to $8: 00 \mathrm{~h}$ was coincident with the expressive decrease in $C_{i}$ recorded at that time. Thus, the activation of the photosynthetic process in the early hours of the day would be responsible for fixing part of this $\mathrm{CO}_{2}$. It occurs in part because, with the maximum opening of the stomata also registered at 8:00 h, there were no significant increases in $C_{i}$ for the levels observed at the beginning of the day.

Therefore, this result indicates that part of the high intercellular $\mathrm{CO}_{2}$ concentration recorded between 6:00 and 7:00 h must have been fixed via photosynthesis, and part of it was lost directly to the atmosphere by simple diffusion that occurs naturally due to differences in $\mathrm{CO}_{2}$ concentration between leaf (around $430 \mathrm{~mol} \mathrm{~mol}^{-1}$ ) and atmosphere (around $350 \mathrm{~mol} \mathrm{~mol}^{-1}$ ), through stomata. In other words, when the photosynthetic process is 
activated in the first hours of the day in parallel to the higher $g_{s}$ rates, these plants start promoting higher $\mathrm{CO}_{2}$ fixation rates while part of this $\mathrm{CO}_{2}$ is naturally lost to the atmosphere. These results are very interesting from a physiological point of view since at the same time they prove a high photosynthetic rate in the early hours of the day; also suggest that oil palm plants should have very high rates of night breathing. Night breathing combined with lower rates of $g_{s}$ at night (possibly null due to the absence of light) would be responsible for the high concentrations of $\mathrm{Ci}$ observed in the early hours of the day. The decrease in $g_{s}$ in plants subjected to water deficit occurs as a water-saving strategy, because the lower the $g_{s}$, the greater the resistance that stomata start to offer to transport water vapor between leaf and atmosphere. Therefore, lower $g_{s}$ values contribute to decreasing water loss via $E$ (Kramer \& Boyer, 1995). Reductions in $g_{s}$ in plants subjected to water deficit is a very common response in different species, including oil palm (Suresh, Nagamani, Ramachanduru, \& Mathur, 2010; Suresh et al., 2012). Both in irrigated plants and underwater deficit of both hybrids evaluated in this experiment, the $g_{s}$ was significantly reduced (mainly between 10:00 to 15:00 h).

Regarding the difference in water vapor pressure between leaf and atmosphere $\left(\delta_{e}\right)$, the higher this value, the greater the tendency of transpiration (Kramer \& Boyer, 1995). Besides, increases in $\delta_{e}$ may stimulate stomatal closure in some species, similar to what occurs in Fagus crenata (Iio, Fukasawa, Nose, \& KakubarI, 2004), Picea abies (Sellin \& Kupper, 2004), Coffea canephora (Pinheiro et al., 2005). Evaluating stomatal behavior of these hybrids to their respective diurnal courses of $\Psi_{w}$ and $\delta_{e}$, it can be inferred that, in irrigated plants, the decreases in $g_{s}$ are related both to the decrease in $\Psi_{w}$ and to the expressive increase in $\delta_{e}$. In contrast, in plants under water deficit, which $\Psi_{w}$ averages did not vary significantly over the day, the decrease in $g_{s}$ seems to be governed by increases in $\delta_{e}$. It should be noted that, both for irrigated plants and underwater deficit, the maximum diurnal $g_{s}$ coincided with the highest values of $\Psi_{w}$ and median values of $\delta_{e}$.

The irrigated plants of both hybrids showed high values of $E$ between 8:00 and 15:00 h, although the $g_{s}$ at these times were lower when compared to those observed at the maximum peak at 8:00 h. Therefore, $g_{s}$ decreases between 8:00 and 15:00 h should partially regulate the excessive water loss by the leaves of the irrigated plants at these times. In contrast, better control of $E$ through stomatal closure occurred in the stressed plants of both hybrids, although this behavior was more remarkable for the BRS C 2501. It is noteworthy that the highest $E$ rates recorded between 8:00 and 15:00 $\mathrm{h}$ coincided with the highest averages of PAR, $T_{f o l}$, and, mainly $\delta_{e}$, which together are physical conditions that favor greater sweating (Kramer \& Boyer, 1995). Considering the specific high heat of the water, it can be considered that the higher $E$ between 8:00 and 15:00 h in irrigated plants is a strategy to control excessive increases in $T_{f o l}$, which diurnal values were also higher in this period. In addition, if the soil water is not limiting, then the greater $E$ favors greater absorption and transport of nutrients from the soil to the aerial part via mass flow in the xylem. On the other hand, the stressed plants of both hybrids showed higher values of $E$ at 8:00 h and this must have occurred due to the diurnal peak of $g_{s}$ in these plants in parallel to median values of $\delta_{e}$. Thus, these plants can capture atmospheric $\mathrm{CO}_{2}$ with the least possible loss of water. This is confirmed by the highest $A / E$ values at exactly this time (8:00 h).

The irrigated plants of BRS C 2501 and BRS Manicoré showed similar patterns of diurnal variations of $A / E$. For these plants, positive $A / E$ values were predominant throughout the day, while negative values were recorded only at the beginning of the day $(6: 00 \mathrm{~h})$ and in the late afternoon $(18: 00 \mathrm{~h})$. The positive values of $A / E$ indicate that the plants of both hybrids showed an excellent ratio between $\mathrm{CO}_{2}$ fixed units to transpired water vapor units. In contrast, the negative $A / E$ values were due to the negative values recorded for $A$.

The diurnal variations of $\Psi_{w}$ and $g_{s}$ exchange in plants under water deficit of both hybrids were substantially different from those obtained for their respective irrigated plants, showing values of $\Psi_{w}, A, g_{s}, E$, and $A / E$ in these plants almost always lower than in their respective irrigated plants. Although under water deficit, it was observed that the maximum peak of $g_{s}$ exchange in the plants of both hybrids also occurred at 8:00 h. Throughout the day, both genotypes showed lower rates of $A, g_{s}, E$, and $A / E$ than their respective irrigated plants. Comparatively, the results obtained indicate that the effects of water deficit were less remarkable for BRS Manicoré plants, showing that it presented a better physiological performance under deficit than BRS C 2501 at the imposed experimental conditions. Additional experiments with these same hybrids under more prolonged water deficit conditions are necessary to better characterize their physiological responses to this stress. The water deficit negatively affects the water status of the plant, which can be evidenced by lower values of $\Psi_{w}$ presented by plants under water deficit about the respective irrigated plants. However, the magnitude of the change in the water status of the plant is an inherent response to each species (Carvalho et al., 2013; Cordeiro et al., 2009; Suresh et al., 2010) or even to different varieties, clones or hybrids of the same species (Méndez, Chacón, Bayona, \& Romero, 2012; Pinheiro, Damatta, Chaves, Loureiro, \& Ducatti, 2005; Suresh et al., 2012). For this reason, with the decrease in $\Psi_{w}$, the $g_{s}$ exchange variables are negatively affected. 
Variations in $\Psi_{w}$ and gas exchange at different times of the day; both under conditions of full irrigation and water deficit, was reported for different species (Carvalho et al., 2013; Cordeiro et al., 2009; Niu, Jiang, Li, Gao, \& Liu, 2003; Wen \& Chen, 2009). In addition to factors related to the species itself (plant factors), the fluctuations observed in $\Psi_{w}, A, g_{s}$, and $E$ over a day also depend, directly or indirectly of factors like the environment, such as the PAR, temperature, relative humidity, deficit of water vapor pressure in the atmosphere, and $\delta_{e}$ (Landsberg, 1986; Sellin \& Kupper, 2004; Heldt, 2005; Pinheiro et al., 2005).

These climatic parameters vary throughout the day and the amplitude of these variations depends on the place or region of study. Although $\mathrm{CO}_{2}$ also influences $A$, its atmospheric concentrations over the day tend to be practically constant, so as not to influence gas exchange excessively.

Plant species present; therefore, different behaviors of gas exchanges over the day, so that each species presents a diurnal curve of $\Psi_{w}$ and gas exchanges that characterize it. Since the water deficit causes decreases in $\Psi_{w}, A, g_{s}$, and $E$ then, the diurnal curves of irrigated plants compared to underwater deficit are different, as shown in Picea abies (Sellin \& Kupper, 2004), Swietenia macrophylla (Cordeiro et al., 2009) and Carapa guianensis (Carvalho et al., 2013).

In seedlings of oil palm hybrids, Suresh et al. (2012) demonstrated that $A$ drops from $6.20 \mu \mathrm{moL} \mathrm{m} \mathrm{m}^{-2} \mathrm{~s}^{-1}$ in irrigated plants to $0.05 \mu \mathrm{moL} \mathrm{m} \mathrm{m}^{-2} \mathrm{~s}^{-1}$ in plants subjected to water deficit, which $\Psi_{w}$ was around -3.5 to $4.0 \mathrm{MPa}$. Méndez et al. (2012) observed that in oil palm hybrids, the decrease in $\Psi_{w}$ from $-0.5 \mathrm{MPa}$ to $-2.0 \mathrm{MPa}$ caused the reduction in $A$ of mean values of $6.3 \mu \mathrm{moL} \mathrm{m}^{-2} \mathrm{~s}^{-1}$ in irrigated plants and $0.8 \mu \mathrm{moL} \mathrm{m}^{-2} \mathrm{~s}^{-1}$ in plants subjected to stress. In this experiment, the effects of water deficit on $A$ of BRS C 2501 and BRS Manicore were very similar to the results obtained by Suresh et al. (2012) and Méndez et al. (2012). That is, for both hybrids the maximum $A$ $(8: 00 \mathrm{~h})$ in the irrigated plants varied between 7 and $8 \mu \mathrm{moL} \mathrm{m}^{-1} \mathrm{~s}^{-1}$, and for plants under water deficit 0.36 and $0.84 \mu \mathrm{moL} \mathrm{m} \mathrm{m}^{-2} \mathrm{~s}^{-1}$. Both Suresh et al. (2012) and Méndez et al. (2012) found no negative $A$ values under stress conditions, which only occurred for BRS C 2501 and BRS Manicoré in the late afternoon.

Among the factors that may harm $A$ under water deficit, it stands out the importance of those inherent to the plant itself, such as the loss of structure and stability of the photosystems, which can manifest itself in the form of photoinhibition or photo-oxidative damage (Foyer \& Shigeoka, 2011). The loss of activity or degradation of enzymes, involved in the biochemical phase of photosynthesis (Silva et al., 2016, 2017), and increase in photorespiration (Atkin \& Macherel, 2009).

Suresh et al. (2010) demonstrated the maintenance of the activity of photosystem in oil palm plants submitted to water potentials up to $-2.5 \mathrm{MPa}$. This was proved through fluorescence analyzes of $\mathrm{Chl} a$, which values, for the maximum quantum efficiency of photosystem II (PS II) (Fv/Fm), were not altered due to the imposed stress.

In this study, although the fluorescence variables of $\mathrm{Chl} a$ were not evaluated and taking into account the results of Suresh et al. (2010), it can be inferred that BRS Manicoré plants under water deficit must have maintained their photochemical capacity at adequate levels, that is, similar to that of irrigated plants. This assumption takes into account that the water deficit suffered by these plants was characterized by a $\Psi_{w}$ in the morning around -2.13 $\mathrm{MPa}$ and the lowest diurnal value of $\Psi_{w}$ in these plants was $-2.40 \mathrm{MPa}$. Besides, the absence of significant changes in the leaf concentration of $\mathrm{Chl} a$ and the significant increase in $\mathrm{CAR}_{T o t}$ are signs of maintaining the structural integrity of photosystems and evidence the importance of carotenoids in the dissipation of excess energy from these plants (Taiz \& Zeiger, 2017). The concentration of $\mathrm{CAR}_{\text {Tot }}$ was also higher in plants under water deficit of BRS C 2501; however, these increases occurred to a lesser extent than in plants of BRS Manicoré. This result allows us to infer that the BRS C 2501 showed less protection capacity of the photosystems through the dissipation of excess energy through the carotenoids and this explains the degradation of chlorophyll that was observed in the stressed plants of this hybrid.

The plants under the stress of both evaluated hybrids showed increases in the activities of the $\mathrm{GLO}_{\mathrm{x}}$ and CAT. This result is an indication that the $A$ in the stressed plants of these hybrids is partly decreased due to increases in photorespiration. In addition, and considering that the increases in the activity of the $\mathrm{GLO}_{\mathrm{x}}$ and CAT were more expressive for BRS C 2501, so it is suggested that this hybrid is more prone to photorespiration than the BRS Manicoré hybrid. Therefore, this explains why the average $A$ maximum was lower for BRS C 2501.

\section{Conclusions}

The pattern of diurnal variations in the $\Psi_{w}$ and gas exchange variables (net assimilation rates of $\mathrm{CO}_{2}, A$; stomatal conductance, $g_{s}$; transpiration, $E$ and instantaneous water use efficiency, $A / E$ ) is similar between plants of BRS Manicoré and BRS C 2501, compared under the same water regime. However, the mean values of $\Psi_{w}, A, g_{s}, E$, and $A / E$ in BRS Manicoré are higher than in BRS C 2501, both under irrigated and water deficit conditions. 
Concerning their respective irrigated plants, the water deficit caused significant increases in the total carotenoids levels of BRS C 2501 and BRS Manicoré, while chlorophyll $a$ content is significantly reduced only in BRS C 2501 and chlorophyll $b$ only in Manicoré.

The water deficit also mediated significant increases in the activities of glycolate and catalase oxidase in both hybrids; however, such increases are more expressive in BRS C 2501 than in BRS Manicoré. For all those reasons, it can be inferred that BRS Manicoré presents a better set of physiological and biochemical responses to tolerate water deficit than BRS C 2501.

\section{References}

Asada, K. (1999). The water-water cycle in chloroplasts: Scavenging of active oxygens and dissipation of excess photons. Plant Molecular Biology, 50, 601-639. https://doi.org/10.1146/annurev.arplant.50.1.601

Atkin, O. K., \& Macherel, D. (2009). The crucial role of plant mitochondria in orchestrating drought tolerance. Annals of Botany, 103, 581-597. https://doi.org/10.1093/aob/mcn094

Bastos, T. X., Müller, A. A., Pacheco, N. A., Sampaio, S. M. N., Assad, E. D., \& Marques, A. F. S. (2001). Zoneamento de riscos climáticos para a cultura do dendezeiro no estado do Pará. Revista Brasileira Agrometeorologia, 9, 564-570. Retrieved from https:/ainfo.cnptia.embrapa.br/digital/bitstream/item/57674/ 1/cap22.pdf

Boari, A. de J. (2008). Estudos realizados sobre o amarelecimento fatal do dendezeiro (Elais guineenses Jacq.) no Brasil (Documentos 348, p. 66). Belém: Embrapa Amazônia Oriental. Retrieved from https://ainfo. cnptia.embrapa.br/digital/bitstream/item/27984/1/Doc348.pdf

Booker, F. L., Reid, C. D., Brunschon-Harti, S., Fiscus, E. L., \& Miller, J. E. (1997). Photosynthesis and photorespiration in soybean [Glycine $\max$ (L.) Merrill] Chronically exposed to elevated carbon dioxide and ozone. Journal of Experimental Botany, 48(315), 1843-185. https://doi.org/10.1093/jexbot/48.315.1843

Bradford, M. M. (1976). A rapid and sensitive method for the quantitation of microgram quantities of protein utilizing the principle of protein-dye binding. Analytical Biochemistry, 72(1-2), 248-254. https://doi.org/ 10.1016/0003-2697(76)90527-3

Carvalho, C. J. R. (2000). Ecofisiologia do dendezeiro (Elaies guineensis Jacq.). In I. de J. M. Viegas \& A. A. Müller (Eds.), A cultura do dendezeiro na Amazônia Brasileira (pp. 89-124). Belém: Embrapa Amazônia Oriental/Manaus: Embrapa Amazônia Ocidental.

Carvalho, K. S., Pinheiro, H. A., Festucci-Buselli, R. A., Silva Júnior, D. D., Castro, G. L. S., Cruz, F. J. R., \& Fujiyama, B. S. (2013). Diurnal changes in leaflet gas exchange, water status and antioxidante responses in Carapa guianensis plants under water-deficit conditions. Acta Physiology Plantarum, 35, 13-21. https://doi.org/10.1007/s11738-012-1043-6

Chia, G. S., Lopes, R., Cunha, R. N. V., Rocha, R. N. C., \& Rios, S. A. (2012). Gene sh e ginandromorfia em inflorescências masculinas de híbridos F1 entre o caiaué e o dendezeiro. Amazonian Journal of Agricultural and Environmental Sciences, 55, 212-219. https://doi.org/10.4322/rca.2012.061

Cordeiro, Y. E. M., Pinheiro, H. A., Santos Filho, B. G., Corrêa, S. S., Silva, J. R. R., \& Dias-Filho, M. B. (2009). Physiological and morphological responses of young mahogany (Swietenia macrophylla King) plants to drought. Forest Ecology and Management, 258, 1445-1449. https://doi.org/10.1016/j.foreco.2009.06.054

Cunha, R. N. V., \& Lopes, R. (2010). BRS Manicoré: hibrido interespecifico entre o Caiaué e o Dendezeiro Africano recomendado para áreas de incidência de amarelecimento fatal (Comunicado Técnico 85, p. 4). Manaus: Embrapa Amazônia Ocidental. Retrieved from https://ainfo.cnptia.embrapa.br/digital/bitstream/ item/63813/1/ComTec-85-2010.pdf

DaMatta, F. M., Maestri, M., Barros, R. S., \& Regazzi, A. J. (1993). Water relations of coffee leaves (Coffea arabica and C. canephora) in response to drought. Journal of Horticultural Science, 68, 741-746. https://doi.org/10.1080/00221589.1993.11516407

FAO (Food and Agriculture Organization of the United Nations). (2016). Faostat. Retrieved from http://faostat3. fao.org/browse/Q/QC/E

Foyer, C. H., \& Shigeoka, S. (2011). Understanding Oxidative Stress and Antioxidative Function to Enhances Photosynthesis. Plant Physiology, 155, 93-100. https://doi.org/10.1104/pp.110.166181 
Gawankar, M. S., Devmore1, J. P., Jamadagni, B. M., Sagvekar, V. V., \& Hameed, K. H. (2003). Effect of water stress on growth and yield of Tenera oil palm. Journal of Applied Horticulture, 5(1), 39-40. http://doi.org/ 10.37855/JAH.2003.V05I01.10

Havaux, M. (1998). Carotenoids as membrane stabilizers in chloroplasts. Trends in Plant Science, 3(4), $147-151$. https://doi.org/10.1016/S1360-1385(98)01200-X

Havir, E. A., \& McHale, N. A. (1987). Biochemical and developmental characterization of multiple forms of catalase in tobacco leaves. Plant Physiology, 84, 450-455. https://doi.org/10.1104/pp.84.2.450

Heldt, H. (2005). Plant Biochemistry (p. 630). San Diego: Elsevier Academic Press.

Homma, A. K. O., Furlan Júnior, J., \& Carvalho, R. A. (2000). Bases para uma política de desenvolvimento da cultura do dendezeiro na Amazônia. In I. de J. M. Viegas \& A. A. Müller (Eds.), A cultura do dendezeiro na Amazônia Brasileira (pp. 11-30). Belém: Embrapa Amazônia Oriental; Manaus: Embrapa Amazônia Ocidental.

IBGE (Instituto Brasileiro de Geografia e Estatistica). (2014). Indicadores por Estados Brasileiros. Retrieved from http://www.ibge.gov.br/estadosat

Iio, A., Fukasawa, H., Nose, Y., \& KakubarI, Y. (2004). Stomatal closure induced by high vapor pressure deficit limited midday photosynthesis at the canopy top of Fagus crenata Blume on Neba mountain in Japan. Trees, 18, 510-517. https://doi.org/10.1007/s00468-004-0327-x

Kramer, P. J., \& Boyer, J. S. (1995). Water Relations of Plants and Soils. Academic Press, San Diego. https://doi.org/10.1016/B978-012425060-4/50003-6

Krug, C., Bittencourt, D. M. C., Barcelos, E., Rodrigues, M. R. L., Angelo, P. C. S., Rocha, R. N. C., ... Lima, W. A. A. (2013). Plano Estratégico da Embrapa Amazônia Ocidental para a Cultura do Dendezeiro (Documentos 102, p. 73). Manaus, AM: Embrapa Amazônia Ocidental.

Landsberg, J. J. (1986). Physiological Ecology of Forest Production. Academic Press.

Lawlor, D. H. (1995). The effects of water deficit on photosynthesis. In N. Smirnoff (Ed.), Environment and Plant Metabolism - Flexibility and Acclimation (pp. 129-156). BIOS Scientific Publishers, Oxford.

Lichtenthaler, H. K. (1987). Chlorophylls and carotenoids: Pigments of photosynthetic biomembranes. In L. Packer \& R. Douce (Eds.), Methods in enzymology (Vol. 148, pp. 350-382). Bad Honnef: Academic. http://doi.org/10.1016/0076-6879(87)48036-1

Méndez, Y. D. R., Chacón, L. M., Bayona, C. J., \& Romero, H. M. (2012). Physiological response of oil palm interspecific hybrid (Elaeis oleifera H.B.K. Cortes versus Elaeis guineenses Jacq.) to water déficit. Brazilian Journal of Plant Physiology, 24(4), 273-280. https://doi.org/10.1590/S1677-04202012000400006

Niu, S. L., Jiang, G. M., Li, Y. G., Gao, L. M., \& Liu, M. Z. (2003). Diurnal gas Exchange and superior resources use efficiency of typical C4 species in Hunshandak Sandland, China. Photosynthetica, 41(2), 221-226. https://doi.org/10.1023/B:PHOT.0000011954.32698.ea

Pinheiro, H. A., Damatta, F. M., Chaves, A. R. M., Loureiro, M. E., \& Ducatti, C. (2005). Drought Tolerance is Associated with Rooting Depth and Stomatal Control of Water Use in Clones of Coffea canephora. Annals of Botany, 96, 101-108. https://doi.org/10.1093/aob/mci154

Sellin, A., \& Kupper, P. (2004). Within-crown variation in leaf conductance of Norway spruce: Effects of irradiance, vapour pressure deficit, leaf water status and plant hydraulic constraints. Annas of Forest Science, 61, 419-429. https://doi.org/10.1051/forest:2004035

Silva, P. A., Cosme, V. S., Rodrigues, K. C. B., Detmann, K. S. C., Leão, F. M., Cunha, R. L., ... Pinheiro, H. A. (2017). Drought tolerance in two oil palm hybrids as related to adjustments in carbon metabolism and vegetative growth. Acta Physiologiae Plantarum, 39(58), 1-12. https://doi.org/10.1007/s11738-017-2354-4

Silva, P. A., Oliveira, I. V., Rodrigues, K. C. B., Cosme, V. S., Bastos, A. J. R., Detmann, K. S. C., ... Pinheiro, H. A. (2016). Leaf gas exchange and multiple enzymatic and non-enzymatic antioxidant strategies related to drought tolerance in two oil palm hybrids. Trees, 30(1), 203-214. https://doi.org/10.1007/s00468-0151289-X

Suresh, K., Nagamani, C., Kantha, D. L., \& Kumar, M. K. (2012). Change in photosynthetic activity in five common hybrids of oil palm (Elais guineenses Jacq.) seedlings under water deficit. Photosynthetica, 50(4), 549-556. https://doi.org/10.1007/s11099-012-0062-2 
Suresh, K., Nagamani, C., Ramachanduru, K., \& Mathur, R. K. (2010). Gas-exchange characteristics, leaf water potential and chlorophyll a fluorescence in oil palm (Elais guineenses Jacq.) seedlings under water stress and recovery. Photosynthetica, 48(3), 430-436. https://doi.org/10.1007/s11099-010-0056-x

Taiz, L., \& Zeiger, E. (2017). Fisiologia e desenvolvimento vegetal (6th ed., p. 858). Porto Alegre: Artmed.

Trindade, D. R., Poltronieri, L. S., \& Furlan Júnior, J. (2005). Abordagem sobre o estado atual das pesquisas para a identificação do agente causal do amarelecimento fatal do dendezeiro. In L. S. Poltronieri, D. R. Trindade, \& I. P. Santos (Eds.). Pragas e doenças de cultivos amazônicos (pp. 439-450). Belém, PA: Embrapa Amazônia Oriental.

Veiga L. S., \& Furia, L. R. R. (2000). Avaliação do dendezeiro como opção para o sequestro de carbono na Amazônia. In I. de J. M. Viegas \& A. A. Müller (Eds.), A cultura do dendezeiro na Amazônia Brasileira (pp. 125-144). Belém, Brazil.

Waraich, E. A., Ahmad, R., Ashraf, M. Y., Saifullah U., \& Ahmad, M. (2011). Improving agricultural water use efficiency by nutrient management in crop plants. Acta Agriculturae Scandinavica, Section B-Soil \& Plant Science, 61, 291-304. https://doi.org/10.1080/09064710.2010.491954

Wen, X., \& Chen, S. (2009). Diurnal changes in gas exchange and chlorophyll fluorescence parameters of Fritillaria cirrhosa and F. delavayi under field conditions. Photosynthetica, 47(2), 191-198. https://doi.org/ 10.1007/s11099-009-0032-5

\section{Copyrights}

Copyright for this article is retained by the author(s), with first publication rights granted to the journal.

This is an open-access article distributed under the terms and conditions of the Creative Commons Attribution license (http://creativecommons.org/licenses/by/4.0/). 